\title{
COMMUNICATION ON DISCLOSURE OF TUBERCULOSIS DIAGNOSIS AND ADHERENCE TO TREATMENT: SOCIAL REPRESENTATIONS OF PROFESSIONALS AND PATIENTS ${ }^{1}$
}

\author{
Roberta Andrea de Oliveira², Fernando Lefêre ${ }^{3}$
}

\begin{abstract}
${ }^{1}$ Article extracted from the dissertation - Representations and meanings about diagnosis revelation of tuberculosis: relations with adherence or non adherence to treatment, presented to the Post-graduate Program in Public Health, Universidade de São Paulo, 2012.

${ }^{2}$ MSc. in Public Health. Department of Public Health Practice, Faculty of Public Health, Universidade de São Paulo. São Paulo, São Paulo, Brazil. E-mail: robertaoliveira@usp.br

${ }^{3}$ Ph.D. in Public Health. Professor, Department of Public Health Practice, Faculty of Public Health, Universidade de São Paulo. São Paulo, São Paulo, Brazil. E-mail: fernandoipdsc@gmail.com
\end{abstract}

\begin{abstract}
Objective: identifying social representations of health professionals and patients with tuberculosis in an initial interview for diagnostic disclosure and analyzing discursive content regarding the relation of this mode of communication during the interview for adherence of these patients to tuberculosis treatment.

Method: a descriptive and qualitative study. A semi-structured interview was conducted with 39 health professionals involved in the initial tuberculosis diagnosis disclosure interview and 34 adult patients undergoing treatment in 22 health units in the southern region of São Paulo (Brazil). Discourse analysis was based on the discussions about "Awareness", developed by Paulo Freire.

Results: a lack of explanations resulted in patients not understanding the diagnosis, abrasiveness by health professionals, the need for health education and how to approach the patient have emerged as conditions that influence patient adherence to treatment.

Conclusion: regarding communication, we have identified a professional exercise that is contrary to promoting patient adherence to treatment, since it does not allow them to critically reflect on their current situation, and consequently does not modify their reality (in choosing adhesion and cure), thus characterizing incompetent communication.

DESCRIPTORS: Communication. Communication barriers. Health promotion. Patient acceptance of healthcare. Interpersonal relations. Health education. Learning. Tuberculosis.

\section{COMUNICAÇÃO NA REVELAÇÃO DO DIAGNÓSTICO E ADESÃO AO TRATAMENTO DA TUBERCULOSE: REPRESENTAÇÕES SOCIAIS DE PROFISSIONAIS E DE PACIENTES}

\section{RESUMO}

Objetivo: identificar as representações sociais de profissionais de saúde e de pacientes com tuberculose sobre a entrevista inicial de diagnóstico da doença, e analisar o conteúdo discursivo, no que se refere à relação deste modo de comunicação, durante a entrevista com a adesão destes pacientes ao tratamento da tuberculose.

Método: estudo descritivo e qualitativo. Realizou-se entrevista semiestruturada com 39 profissionais de saúde envolvidos com a entrevista inicial de diagnóstico da tuberculose e 34 pacientes adultos em tratamento, em 22 unidades de saúde da região sul de São Paulo (Brasil). A análise dos discursivos foi baseada nas discussões sobre "Conscientização", desenvolvidas por Paulo Freire.

Resultados: a ausência de explicações e consequente não entendimento sobre o diagnóstico, a brutalidade de profissionais da saúde, a necessidade de educação em saúde e a forma de abordar o paciente surgiram como condições que influenciam a adesão ao tratamento por parte do doente.

Conclusão: identificou-se um exercício profissional, no que se refere à comunicação, contrário à promoção da adesão ao tratamento por parte do paciente, já que não permite a ele uma reflexão crítica sobre a situação atual, e, consequentemente, uma não modificação da sua realidade (escolha pela adesão e cura), caracterizando, portanto, uma comunicação não competente.

DESCRITORES: Comunicação. Barreiras de comunicação. Promoção da saúde. Aceitação pelo paciente de cuidados de saúde. Relações interpessoais. Educação em saúde. Aprendizagem. Tuberculose. 


\title{
COMUNICACIÓN EN LA REVELACION DEL DIAGNOSTICO Y ADHESION AL TRATAMIENTO DE LA TUBERCULOSIS: REPRESENTACIONES SOCIALES DE PROFESIONALY PACIENTES
}

\begin{abstract}
RESUMEN
Objetivo: identificar las representaciones sociales de profesionales de salud y pacientes con tuberculosis sobre la entrevista inicial del diagnóstico de la enfermedad y analizar el contenido discursivo en el que se refiere a la relación de este modo de comunicación, durante la entrevista con la entrevista con la adhesión de estos pacientes al tratamiento de la tuberculosis.

Método: investigación descriptiva de abordaje cualitativo. Se realizó entrevista semi-estructurada con 39 profesionales de salud involucrados con la entrevista inicial del diagnóstico de la tuberculosis y 34 pacientes adultos en tratamiento, en 22 unidades de salud de la región sur de São Paulo (Brasil). El análisis de los discursos fue basado en las discusiones sobre "conscientización", desarrollados por Paulo Freire.

Resultados: la ausencia de explicaciones y consecuente no entendimiento sobre el diagnostico, la brutalidad de profesionales de la salud y la necesidad de educación en salud y la forma de abordar al paciente surgieron como condiciones que influyeron en la adhesión al tratamiento por parte del enfermo.

Conclusión: se identificó un ejercicio profesional, en lo que se refiere a la comunicación, contrario a la promoción de la adhesión al tratamiento por parte del paciente, ya que no le permite la reflexión crítica sobre la situación actual y, consecuentemente, la no modificación de su realidad (elección por la adhesión y cura), caracterizando, por tanto, una comunicación no competente.
\end{abstract}

DESCRIPTORES: Comunicación. Barreras de comunicación. Promoción de la salud. Aceptación de la atención de salud. Relaciones interpersonales. Educación en salud. Aprendizaje. Tuberculosis.

\section{INTRODUCTION}

The work of the health professional is based in human relations, and it is not possible to not consider the communicative process that is inserted in these relations. One of the tasks of health professionals is therefore to decode, decipher and perceive the meaning of the message expressed by the patient, and then to elaborate a coherent care plan. ${ }^{1}$ Thus, if we take the disclosure of a diagnosis as an example for which only resulting information is transmitted, we cannot translate that as care.

Adequate communication is one that attempts to reduce conflicts, misunderstandings, and above all, achieves defined goals in interacting with the patient. It is bi-directional, and needs to respond and to validate messages, both verbally and physically (proximity, posture, eye contact); however it can also be a communication that negatively influences the situation when it does not occur in this way. ${ }^{1}$

For communication to be considered appropriate, it must be suitable to the situation, the person, the time/moment, and it must reach a definite goal. That is, it implies an earlier preparation considering what will be transmitted, who will transmit it and who will receive it, as well as the technique that will be employed. ${ }^{1}$

Much is discussed about the proper communication of the health professional with the patients; however, this may be a previous problem, as we lack studies on how to train teachers so they can communicate well and also pass this technique on to their students. ${ }^{2}$

In a study on the perception of nursing teachers about the factors that influence their competence in teaching, they responded to the Scale of Factors Influencing Perception of Competencies for the Exercise of Teaching. ${ }^{3}$ Considering the specific factors investigated by this scale, teachers working in Lato sensu showed a greater perception (statistically significant difference) in their interpersonal skills (trust relationship and effective knowledge exchange), probably due to the more practical characteristic of this education level. ${ }^{4}$ In other words, interpersonal education/communication/relations, intrinsic characteristics of doing education and doing healthcare influence the competence of the professional educator/health professional when they are in practice, and in direct intervention with one another.

Communicating a diagnosis can be perceived as the communication of bad news. The concept of bad news has been defined as any information that involves a drastic change in a negative sense to a person's life. ${ }^{5-7}$ The oncology area includes the most studies on this theme, since health professionals who provide cancer care are in permanent contact with situations of pain, suffering and loss. Training focuses on preparing this professional to disclose such news. ${ }^{8}$

The news of tuberculosis diagnosis as a curable disease entails a drastic change in the patient's life for a long period of treatment (traditionally six months), with risk of death if there is no cure, including strong adverse reactions to various medications. However, studies regarding the disclosure of tuberculosis diagnosis focus on patient's adherence or non-adherence to treatment, instead of on the behavior of the health professional during disclosure regarding the quality of such communication. In general, these studies are aimed at describing the 
characteristics of patients who abandon treatment, as well as adherence facilitators. The importance of a humanized relationship as a facilitator in the service has only been discreetly mentioned. ${ }^{9-10}$

Adherence or non-adherence to a treatment may be a consequence of diagnosis disclosure. Adherence has been studied by health professionals because it is the fundamental point for treatment effectiveness. Non-adherence has become important in recent decades and is among the concerns of health professionals. ${ }^{11-12}$ This is a legitimate concern and it relates to health professionals' ability to communicate well and promote teaching/learning, since it is a pedagogical relationship in the sense that it needs access to the other so that they can empower themselves enabling them to actively seek change in the situation/problem (illness). The necessary and required pedagogical competence for health professionals could be invested and developed from its training, and for that to occur their teachers would also need to have communicational competence in order to widely develop the pedagogical potential in the classroom. ${ }^{2}$

The term adherence in medical and health literature is used to refer to the patient's follow-up to therapeutic recommendations made by a health professional, whether they are drug treatments or other health-related actions. The term compliance used by English authors (which is equivalent to concordância in the Portuguese language) was developed by R. Bryan Hynes in 1979, and is used as the patient's ability to follow prescription to treatment. This term is criticized for being based on a superficial relationship in which the clinician decides and the patient only obeys. ${ }^{13}$

The term adherence (which means adesão in Portuguese) appears as a proposal to diminish the clinician's power in the decision regarding treatment, proposing a better relationship between health professionals and patients in which both are responsible for decision making.

Specifically as it pertains to performance in the area of tuberculosis, the definition of adherence can be understood as the patient's consumption of the drug corresponding to the prescribed treatment. ${ }^{14}$ As we can see, overestimation of the recommendation and the consumption of medication in detriment to the established relationship between professionals and patients is evident. ${ }^{15}$

Regarding tuberculosis treatment, the Program for the Control of Tuberculosis of the Municipality of São Paulo performs actions in an attempt to resolve some of the influencing factors for non-adherence to treatment: offering monthly food packages and round trips to the health unit to take or to pick up medication, an action that seeks to remedy some socioeconomic factors. ${ }^{14}$ Free drug distribution and the preference for Directly Observed Therapy (DOT) in the health unit seek to remedy some points of the factors related to the service and health professionals. Standardizing treatment regimens and periodic consultations to follow up patient's evolution, as well as side effects, seek to remedy some points related to treatment.

Adherence to treatment is associated to health professionals' relationship with the patient and the former should establish productive dialogue with patients, respecting their cultural beliefs. ${ }^{16}$ This influence of the health professional and patient relationship for adherence is clear, however it is not the only that can explain adherence or not. ${ }^{11}$ Still, [... " "care management presents itself as a possibility, since it has technologies to act on the individuals' singularities and needs, whether permanent or momentary, aiming to reestablish their well-being" ${ }^{12: 2}$

For the theoretical design underlying the present study, we presuppose the understanding that adherence is a positive option for patients to comply with therapeutic recommendations, through dialogue established between the health professional and patient, in the initial diagnostic (disclosure) interview. We understand dialogue as a form of communication that considers patient's opinions, beliefs and doubts; meaning, a form of communication that places them as an active subject to achieve healing.

This open communication that empowers individuals is part of the actions in the broader context of health. With the founding of the World Health Organization (WHO) in 1948, a new conception of health was inserted, no longer defined as an absence of disease, but rather as a state of well-being related to biological, psychological, and social states. ${ }^{17}$

In the context of this work developed in the broader context of health, we understand health promotion, which according to the Health Promotion Glossary, is the process of enabling people to increase control over and improve their health and collective health. ${ }^{18}$

Health promotion presents a change in the way of thinking and acting on health and its determinants, changing the meaning of health, which has traditionally been understood as "absence of disease". Now we can understand health as a process (health-disease) that is part of greater or lesser social imbalance. In other words, health 
promotion focuses on an expanded health concept, encompassing the environment, production modes and quality of life. ${ }^{19}$

Health promotion is referenced by a concept of health that aims to identify and reinforce the potential of individuals and groups, understanding that there is a social production of health. Thus, it is possible to meet the needs of the population through integrated actions on health determinants and conditions; ${ }^{20}$ actions linked to effective communication and health promotion, even in situations that include bad news.

Therefore, given the effective techniques of communication and educational work for health promotion in the face of disclosing bad news and considering healthcare outcomes, the research problem was translated into the following question: In what way does the initial diagnostic (disclosure) interview - which is one of the various moments of dialogue that occur between health professionals and patients - contribute to adherence or non-adherence of treatment for tuberculosis, according to health professionals' and patients' perspectives?

Thus, the objective was to identify the social representations of health professionals and tuberculosis patients about the initial diagnosis interview of the disease, and to analyze the discursive content regarding the way this communication by health professionals forms a relationship with their patients, and patients' adherence to tuberculosis treatment.

\section{METHOD}

This was a descriptive and qualitative study capturing health professionals and patients' social representations regarding the form of communicating/disclosing the diagnosis of tuberculosis and adherence to treatment. This work analyzed the discursive content based on the "Awareness" discussions developed by Paulo Freire. A semi-structured interview (recorded and then transcribed, and the transcript was not reviewed by the participant) was conducted with 39 professionals involved in the initial diagnostic interview (inclusion criterion), and with 34 adults patients undergoing tuberculosis treatment (inclusion criterion), in 22 health units in the southern region of São Paulo and between the period from October 2010 to February 2011. The interviews were conducted at the health units, with an average duration of 15 minutes.
More specifically, there were 22 basic health units (BHUs) in the Campo Limpo Health Surveillance Supervision (SUVIS) of the Regional Health Coordination (CRS) in the city of São Paulo (from a total of 24 SUVIS units). This SUVIS was chosen since it is the most well-organized in terms of the flow of the Tuberculosis Control Program (PCT), and for having the best performance indicators for this program, despite having the same difficulties in reaching the targets for treatment adherence by the patients.

Two units were used for pre-testing the interview scripts, which then underwent some changes. Of the 22 BHUs that remained for applying the definitive research, nine units at the time of the interviews were under the administration of the Sociedade Beneficente Israelita Albert Einstein and 13 units under the administration of the Centro Universitário Adventista de São Paulo (UNASP).

QualiQuantiSoft ${ }^{\circledR}$ software was used in order to organize the individual speeches into social representation structures, obtaining Discourses of the Collective Subject (DCS) as the product for analysis.

The basic sociological assumption is that DCS is the symbolic expression of the social field to which all in that group belong. ${ }^{21}$ Through discourse it is possible to visualize social representation, and not in an artificial way, such as in charts, tables and categories; but in a lively and direct way, since it is through discourse that real and concrete people express themselves. ${ }^{22}$

In this way, collective stories that reflect the narrative codes shared by a society, a culture or a group are obtained. ${ }^{23}$

There were individual interviews with semistructured questions for expressing social representations. Both the interview script for health professionals and patients had some initial questions to characterize the population, and three questions on the communication mode in the initial diagnostic interview. The first question asked whether this moment of dialogue meant something special (for professionals) and how it occurred (for patients); the second question asked how the diagnosis could be disclosed in order to motivate the patient to followup with treatment (for both); and finally, the third question asked what causes patients to abandon treatment (for both).

After organizing the speeches through the DCS method, they were analyzed regarding the mode of communicating the diagnosis based on the six key ideas presented by the Brazilian educator Paulo Freire, and which were adapted for this research. ${ }^{24}$ 
The guiding items of what to look for (or the absence of) in the participants' speeches are presented below. The items were structured based on Paulo Freire's descriptions of key ideas and they represent attempts to establish (or hinder) effective and adequate communication:

- Asking about the patient's living environment;

- Cultural analysis of the patient;

- Pre-fabricated education on the part of the professional;

- $\quad$ Reflection on the patient's situation and environment;

- $\quad$ Domesticating a patient which prevents a reflection on what is happening;

- Communication that leads to reflection by the patient;

- Lead the patient to a process of temporary recognition;

- $\quad$ Reducing the patient to an object;

- Lead the patient to a process of recognizing their social relationships;

- Attempt to bring the patient to a critical choice;

- Promote reflection on the patient's life context;

- Try to establish dialogue with the patient;

- Juxtaposition of information not actually incorporated by the patient;

- Communication that enables a quest for critical and creative experience by the patient;

- Communication that seeks to capture timely themes and that are involved with the central issue of the patient's life and illness;

- $\quad$ Suggest changes in facing the emergence of "the news" for the patient;

- Communication focused on an attempt to allow the patient to become an active subject in facing the problem;

- Search for an authentic and liberating communication by the professional;

- $\quad$ Subjugation of the patient by the professional.

The research project was presented to two Ethics Committees, corresponding to the ethical principles in research with human beings at the Faculdade de Saúde Pública, Universidade de São Paulo (USP) and the Secretaria Municipal de Saúde de São Paulo (SMS-SP). Approval opinions were: Research Number 2145/COEP registration number 307/10 (FSP-USP) and CAAE number 0123.0.162.000-10/ Opinion number 287/10 (SMS-SP). The study was developed within the ethical requirements and with the Free and Informed Consent Forms duly signed in duplicate. Participants received feedback on the research results at the end of the study.

\section{RESULTS}

Initially, the aim was to conduct interviews with 44 patients (two in each of the $22 \mathrm{BHU}$ ) and with 44 health professionals (two in each of the $22 \mathrm{BHU})$. This total was not reached. A total of 34 interviews with tuberculosis patients and 39 interviews with health professionals involved in the initial tuberculosis diagnosis disclosure interviews were obtained. This is justified by the following facts: one of the units did not agree to participate in the study; some of the units did not have more than one patient being treated, or more than one professional involved in the diagnostic disclosure; and in other units, even when there were two professionals and two patients present, some refused to participate in the study.

Among the 34 patients interviewed, in relation to the semi-structured question number 1 (Tell me about the consultation in which you first received the news about having tuberculosis), 35 key ideas were unveiled, comprising a total of ten different categories. As an example, the DCS of one of the categories is presented below, which shows a situation that does not contribute to tuberculosis treatment adherence.

\section{The news on the patient's condition was given directly, without further explanation}

This category had five central ideas as a contribution.

[...] They called me there to tell me that I had tuberculosis [...] the doctor told me that it was suggestive tuberculosis [...]. Look $V$ [...], you have tuberculosis [...]. He looked at my face and simply said: You have tuberculosis, and gave me no further explanation [...].

Still among the patients and regarding the semi-structured question number 2 (How could this news be given so that the patient would feel motivated to do the treatment?), 36 central ideas were retrieved that altogether comprised 14 different categories. Here is an example of the DCS of one of the categories, which shows a situation that contributes to tuberculosis treatment adherence:

\section{Further explaining what the disease involves}

This category had five central ideas as contribution.

Explaining the benefits better, how it is, what it causes [...]. Uh... the right way, explaining everything correctly, the pros and cons and the influence of treatment. They have to tell the patient that it is a disease that 
... which is passed on/contagious, as they explained to me, passed on the bus, by coughing, by virus, anyway... And they explained that the treatment was simple, that I would only have to do a follow-up for six months, and that after six months I would continue leading a normal life with no extra problem in the future, so [...].

Further, with respect to the semi-structured question number 3 in which three options were chosen on what can lead a patient to withdraw from treatment and the possibility of explaining the chosen response (the options involved abrasive treatment by the health professional, lack of understanding of the explanations about treatment or the treatment seems too complicated to be done), 40 central ideas were captured, comprising a total of 14 different categories. An example of the DCS of one of the categories is given below, showing a situation that does not contribute to tuberculosis treatment adherence.

\section{Patients may give up treatment due to the abrasiveness/insensitivity of some professionals} bution.

This category had six central ideas as contri-

[...] Well, the person is already sick, and if they are not treated well, they become more discouraged and give up. Because they are already discouraged, you already have a problem, you have to do the treatment properly, follow up with the treatment [...]. Some (doctors) are quite rude, they make the person give up on the treatment [...]. You are sick and you are treated with rudeness?... That's annoying, right? [...].

Among the 39 professionals interviewed in relation to semi-structured question number 1 (Is there anything special about the consultation where the patient is first told that he or she has tuberculosis? Tell me a little about it), 60 central ideas were captured, comprising a total of 20 different categories. An example of the DCS of one of the categories is shown below, presenting a situation that contributes to tuberculosis treatment adherence:

\section{It is important to do the educational part so that this patient multiplies information in their context} tribution.

This category had one central idea as a con-

[...] It is important to emphasize the causes that may have led (to the disease) so that it does not happen again, because a relapse can occur from abandoning treatment, or even due to low immunity further ahead [...]. So, take care! I think it is not difficult for them to understand, it is not the pathophysiology of the disease, it is the issue of how tuberculosis is transmitted, how it is passed on, educating (them) that it can pass to a neighbor, not the household contacts, because the household contacts come to $u s$, but in the region itself [...].

Still among the professionals and in relation to the semi-structured question number 2 (How could this news be given so that the patient feels motivated to adhere to treatment?), 57 central ideas were captured composing a total of 18 different categories. An example of the DCS of one of the categories is presented below, depicting a situation that contributes to tuberculosis treatment adherence.

\section{Through how the patient is approached}

This category had one central idea as contribution.

[...] Each professional acts in a different way, right? [...]. I think it's the way the professional treats the patients the first time, their first contact. So, I guess that you have to dedicate yourself to this patient, you have to ... give greater attention to them and their family, because it involves the entire family [...]. So, I think that if the professional shows more attention, if he devotes more to this patient, adherence will also be better, right? [...].

Regarding the semi-structured question number 3 in which three options were chosen on what can lead a patient to withdraw from treatment, and the possibility of explaining the chosen response, exactly as with the patients, 58 central ideas were captured composing a total of 13 different categories. An example of the DCS of one of the categories is presented below, which shows a situation that does not contribute to tuberculosis treatment adherence.

\section{Patients might give up treatment because they do not understand the explanations about it}

This category had nine central ideas as a contribution.

It all depends on how we talk, explain... right? If you have their attention, a clear dialogue... because it depends on who speaks it, on who is giving the explanation [...]. If you do it right and clear all their doubts, I really think that it's easier for them to do the treatment. See, here, we work in a multiprofessional unit, which has several people committed to being able to follow-up the patient and we have very good success [...]. The patient, you need to explain things to them in a way that is accessible for them [...]. 


\section{DISCUSSION}

After all the work organizing the speeches of all the participants to the three questions, in central ideas into categories, and finally into DCS (generating a large amount of results, briefly exemplified in the previous item), all the material was analyzed regarding the diagnosis communication mode, as based on the six key ideas presented by the Brazilian educator Paulo Freire which were adapted for this research. ${ }^{26}$ Due to the impossibility of presenting all the discussions of all the results, we chose to present the most relevant discussions.

We observed that not only physicians, but also nurses and nursing assistants disclosed the tuberculosis diagnosis to patients of the 22 Basic Health Units (BHU) in the Campo Limpo Supervision of Health Surveillance (SUVIS) of São Paulo, between the end of 2010 and the beginning of 2011, and that those interviewed are more concerned about the content to be said than the form of communicating it.

In their speeches, most of the interviewed professionals revealed that they follow a list to give the news to the patient, a check list of things they cannot forget to mention. This reveals the health professional's need to be guided by protocols and shows their difficulty in dealing with the unexpected and with the subjectivity that can be expressed by the patient upon receiving news of a serious illness. Moreover, few professionals believe that the best way to disclose the diagnosis so that patients will adhere to treatment is by making them accountable for their outcome, provoking fear into them or offering material incentives as a bargain for them to adhere (there is monthly distribution of a basic basket in the city of São Paulo, BHU round trip transportation ticket, snacks after taking the pills at the BHU, and a snack voucher for them to feed themselves after they leave the BHU for patients who do the directly observed treatment - DOT. All of these "benefits" are considered strategies to improve treatment adherence).

Considering Freire's key ideas, following an identical check-list for all patients is not considering the specificities of communication with each patient in a singular way; blaming the patient for the treatment outcome may suggest that the responsibility of the service is only in diagnosing and providing treatment; offering material incentives does not translate to a pedagogical attitude, but instead of dependence, and it is also not possible to control how the patient will conduct his treatment, so that they can receive more or less material incentives; and finally, provoking fear into them to achieve what one wants can translate as an attempt by the professional to infantilize the patient, as if they were subjects incapable of understanding and reflecting, as if fear were the only way to educate them. According to the guiding items of the analysis (constants in the methodology item), these behaviors characterize pre-fabricated education, domestication, reducing the other to an object and subjugation. They are distant attitudes of competent communication/ education in order to make adherence viable. ${ }^{24}$

The patients interviewed said that some people may withdraw from the treatment after the news when there are still doubts about what the disease involves; some revealed that they lived the experience of the news having been given directly without further explanation; some further believe that the best way to give this news would be to explain everything involving the disease and which patients give up when they do not understand how the treatment works, when they are treated abrasively, are disrespected, or when they do not receive attention from the service. According to the guiding items for analysis, these behaviors are related to a juxtaposition of information that is not really incorporated by the patient, as well as subjugation with regard to abrasive/insensitive treatment. ${ }^{24}$

We must understand that communication with others does not end with words. In a conversation, messages are processed and there is a construction and reconstruction of senses, knowledge and thoughts. Thus, both verbal and non-verbal communication also promotes marks in people by the language expressed using gestures, facial expressions and emotions. ${ }^{25}$ In this (re)construction of meanings, we can also include the silence, body language, the distance/space between individuals, as well as the arrangement of objects in the environment. ${ }^{26}$

In a study on the educational role of nurses in adherence to systemic arterial hypertension treatment (also a chronic disease), an integrative review of the literature was carried out giving rise to four thematic categories which describe factors that influence treatment adherence. Two categories converge the points discussed here in this research. One of them is continuing education in health as a political process that discourages, transforms and emancipates the subjects. ${ }^{27}$ And the other is the lack of knowledge about the disease by the patient for which nurses must have their educational role in motivating and proposing strategies. ${ }^{27-28}$

All educational/communicative action must be preceded by reflection on the person and their life. Explaining what the disease involves may 
encompass the patient's social context, which brings more meaning to the provided information. Otherwise, education becomes pre-fabricated and inoperative. Perceiving the other is understanding the situation by considering the other's personal desires and needs. ${ }^{29}$

In analyzing another study also on adherence to hypertension treatment in the context of primary care (and also in an integrative review), the studies with the highest level of evidence (level II) mostly evaluate educational actions with the patients, pointing to this tool as a collaborator to increase adherence. Six articles dealing with the health professional/ patient relationship describe the relationship of trust as a contributing factor, providing a clear understanding to the patient about the proposed treatment. All studies related to educational actions have positive adherence results. ${ }^{30}$

Man's relations within their life contexts are confrontational. ${ }^{24}$ Hence, individual relations with each other are of confrontation, so that they are tempted to reduce the other to the condition of an object. ${ }^{24}$ In this way, patients and health professionals experience the same moment of interlocution in a different way; professionals only provide information, while patients want explanations. This shock reflects subjects' response to confrontation with other subjects. It's an attempt to stop the other from modifying them. It is a protection barrier, a resistance, so that the reality of the other does not invade their reality. ${ }^{24}$

Health professionals "[...] can act by broadening the critical awareness of individuals, families and communities for the empowerment of healthy life choices. Thus, it is essential that its practice is linked and based on an educational proposal of social transformation [...]". 27:476

\section{CONCLUSION}

We conclude that the process of disclosing a tuberculosis diagnosis in the studied context does not use the communication opportunity to motivate patient treatment adherence. Freire's pedagogical and liberating way of communicating does not appear in relevant quantity or quality in the interviewees' speeches, it is not valued as something to be done (by professionals), nor is it revealed as something that has been experienced or that could be experienced (by patients).

This study has produced a reflection on the importance of communication when we need to reach others in order to make them an active subject in transforming a reality that they are experiencing (suffering), since it is through this tool that people reveal positive feelings such as interest in the relationship being established, or negative feelings such as indifference, disregard, etc.

It is a professional exercise contrary to health promotion since it does not allow the patient to critically reflect on the current situation (the illness), so that they become active in modifying their reality (health).

Among Paulo Freire's key ideas adapted to guiding items for DCS analysis, very few can be drawn from the social representations of health professionals and patients regarding what translates as competent communication for adherence, such as the suggestion of change in relation to "the news", as mentioned by a few participants. However, none of the DCS address the possibility of questioning and reflecting on the patient's livelihood, and even less on the process of critical choice. Most of the representations are involved in prefabricated education, with domestication of the patient and their subjugation.

Thus, the discursive content analyzed in the form of communication between health professionals and their patients, and the relationship between this communication and patient adherence to tuberculosis treatment have pointed to an interpersonal communication that is not competent, nor based on Paulo Freire's indications on how a truly educational and transformative communication should be.

\section{REFERENCES}

1. Silva MJP. Comunicação tem Remédio: a Comunicação nas Relações Interpessoais em Saúde. São Paulo: Ed. Loyola; 2011.

2. Amorim RKFCC, Trovo MM, Püschel VAA, Silva MJP. Formação docente em comunicação não verbal: avaliação de docentes em um projeto piloto. Rev Saúde [Internet]. 2015; [cited 2016 Jun 22]; 9(1):63-75. Available from: http://revistas.ung.br/index.php/ saude/article/view/1988

3. Nassif VMJ, Hanashiro DMM, Torres RR. Fatores que influenciam na percepção das competências para o exercício da docência. Rev Bras Educ [Internet]. 2010 [cited 2016 Jun 22]; 15(44):364-79. Available from: http://www.scielo.br/scielo.php?script=sci_ arttext\&pid=S1413-24782010000200012

4. Santos CCM, Puggina ACG, Pereira LL. Fatores que influenciam a percepção de professores de enfermagem das competências na docência. REFACS. [Internet] 2016; [cited 2016 Jun 22]; 4(2):86-97. Available from: http:/ / www.uftm.edu.br/revistaeletronica/index. php/refacs/article/view/1640 
5. Buckman, R. How to break bad news: a guide for health care professionals. Baltimore (US): The Johns Hopkins University Press; 1992.

6. Ptacek JT, Eberhardt TL. Breaking bad news - a review of the literature. JAMA. 1996; 276(16):496-502.

7. Miranda J, Brody RV. Communicating bad news. Western J Med [Internet]. 1992; [cited 2016 Feb 23]; 156(1):83-5. Available from: http://www.ncbi.nlm. nih.gov/pmc/articles/PMC1003165/?page=1

8. Souza RAP, Souza SR. Um cuidado complexo: comunicando as más notícias em oncologia. Rev Pesq: Cuid Fundam On-line [Internet]. 2012 [cited 2016 Feb 23]; 4(4):2920-9. Available from: http://www.seer. unirio.br/index.php/cuidadofundamental/article/ view/1772

9. Queiroz R, Nogueira PA. Diferenças na Adesão ao Tratamento da Tuberculose em Relação ao Sexo no Distrito de Saúde da Freguesia do Ó/Brasilândia. Saúde Soc [Internet]. 2010; [cited 2016 Feb 23]; 19(3):627-37. Available from: http:/ / www.scielo.br/ pdf/sausoc/v19n3/14.pdf

10. Chirinos NEC, Meirelles BHS. Fatores associados ao abandono do tratamento da tuberculose: uma revisão integrativa. Texto Contexto Enferm [Internet]. 2011 [cited 2016 Feb 23]; 20(3):599-406. Available from: http://www.scielo.br/pdf/tce/v20n3/23

11. Leite SN, Vasconcellos MPC. Adesão à terapêutica medicamentosa: elementos para a discussão de conceitos e pressupostos adotados na literatura. Cien Saúde Coletiva [Internet]. 2003; [cited 2015 Nov 10]; 8(3):775-82. Available from: http:/ / www.scielo.br/ pdf/csc/v8n3/17457.pdf

12. Coelho APC, Larocca LM, Chaves MMN, Felix JVC, Bernardino E, Alessi SM. Healthcare management of tuberculosis: integrating a teaching hospital into primary health care. Texto Contexto Enferm [Internet]. 2016 [cited 2016 Aug 23]; 25(2):1-7. Available from: http:/ / www.scielo.br/pdf/tce/v25n2/0104-0707tce-25-02-0970015.pdf

13. Osterberg L, Blaschke T. Drug therapy: adherence to medication. N Engl J Med [Internet]. 2005 [cited 2015 Nov 10] 353(5):487-97. Available from: http:/ / www. nejm.org/doi/full/10.1056/NEJMra050100

14. World Health Organization. Adherence to long-term therapies: evidence for action [Internet]. Geneva $(\mathrm{CH})$ : WHO; 2003 [cited 2015 Nov 10]. Available from: http://apps.who.int/medicinedocs/en/d/Js4883e/

15. Oliveira RA, Lefèvre F. Representações sociais sobre a revelação do diagnóstico da tuberculose e suas relações com a adesão ao tratamento. Pesquisa em andamento. Rev Eletron Comun Inf Inov Saude [Internet]. 2012 [cited 2015 Nov 10]; 6(1). Available from: http:/ / www.reciis.icict.fiocruz.br/index.php/ reciis/article/view/615/1256

16. Dias AM, Cunha M, Santos AMM, Neves APG, Pinto AFC, Silva ASA, et al. Adesão ao regime terapêutico na doença crônica: revisão da literatura. Millenium
[Internet]. 2011 [cited 2015 Nov 10]; 40:201-19. Available from: http://www.ipv.pt/millenium/ Millenium40/14.pdf

17. Buss PM,Filho AP. A saúde e seus determinantes sociais. PHYSIS: Rev Saúde Coletiva [Internet]. 2007 [cited 2015 Nov 10]; 17(1):77-93. Available from: http://www.scielo.br/pdf/physis/v17n1/ v17n1a06.pdf

18. World Health Organization. Division of Health Promotion, Educations and Communications. Health Promotion Glossary [Internet]. Geneva (CH): WHO; 1998 [cited 2015 Nov 10]. Available from: http:/ / www.who.int/healthpromotion/about/HPR \% 20 Glossary\% 201998.pdf

19. Lefrève $F$, Lefrève AMC. Promoção de saúde ou a negação da negação. Rio de Janeiro (RJ): Vieira \& Lent; 2004.

20. Westphal MF. Promoção de saúde: uma nova agenda para a saúde. In: Rocha AA, Cesar CLG, Ribeiro H. Saúde Pública: Bases Conceituais. $2^{\mathrm{a}}$ ed. São Paulo (SP): Ed. Atheneu; 2013.

21. Lefèvre F, Lefèvre AMC, Teixeira JJV, organizadores. O discurso do sujeito coletivo: uma nova abordagem metodológica em pesquisa qualitativa. Caxias do Sul (RS): UCS; 2000.

22. Lefèvre F, Lefèvre AMC. Discurso do sujeito coletivo: um novo enfoque em pesquisa qualitativa (desdobramentos). Caxias do Sul (RS): UCS; 2003.

23. Lefèvre F, Lefèvre AMC. Discourse of the collective subject: social representations and communication interventions. Texto Contexto Enferm [Internet]. 2014 [cited 2016 Aug 23]; 23(2):502-7. Available from: http:/ / www.scielo.br/pdf/tce/v23n2/0104-0707tce-23-02-00502.pdf

24. Freire P. Conscientização - teoria e prática da libertação: uma introdução ao pensamento de Paulo Freire. São Paulo (SP): Cortez \& Moraes; 1979.

25. Ferreira MA. A comunicação no cuidado: uma questão fundamental na enfermagem. Rev Bras Enferm [Internet]. 2006 [cited 2016 Jun 22]; 59(3):327-30. Available from: http://www.scielo.br/pdf/reben/ v59n3/a14v59n3.pdf

26. Amorim RKFCC, Silva MJP. Effective/efficacious nonverbal communication in the classroom: the perception of the nursing lecturer. Texto Contexto Enferm [Internet]. 2014 [cited 2016 Aug 23]; 23(4):86270. Available from: http://www.scielo.br/pdf/tce/ v23n4/0104-0707-tce-23-04-00862.pdf

27. Costa YF, Araújo OC, Almeida LBM, Viegas SMF. O papel educativo do enfermeiro na adesão ao tratamento da hipertensão arterial sistêmica: revisão integrativa da literatura. Mundo da Saúde [Internet]. 2014 [cited 2016 Jun 22]; 38(4):473-81. Available from: http://www.saocamilo-sp.br/pdf/mundo_ saude/155566/A12.pdf

28. Silva SSBE, Colosimo FC, Pierin AMG. O efeito de intervenções educativas no conhecimento 
da equipe de enfermagem sobre hipertensão arterial. Rev Esc Enferm USP [Internet]. 2010 [cited 2016 Jun 22]; 44(2):488-96. Available from: http:/ / www.scielo.br/scielo.php? script $=$ sci $_{-}$ arttext\&pid=S0080-62342010000200035

29. Prochet TC, Silva MJP. Proxêmica: as situações reconhecidas pelo idoso hospitalizado que caracterizam sua invasão do espaço pessoal e territorial. Texto Contexto Enferm [Internet]. 2008 [cited 2016 Feb 16]; 17(2):321-6. Available from: http://www.scielo.br/scielo.php?script=sci arttext\&pid=S0104-07072008000200014

30. Moura AA, Godoy S, Tognoli SH, Mendes IAC. Adesão ao tratamento da hipertensão arterial no contexto da atenção primária à saúde: revisão integrativa. Rev Enferm UFPE [Internet]. 2015 [cited 2016 Jun 22]; 9(4):7420-30. Available from: http:/ / www.revista.ufpe.br/revistaenfermagem/index. $\mathrm{php} /$ revista/article/view/7363 